JOURNAL OF SECURITY AND SUSTAINABILITY ISSUES ISSN 2029-7017 print/ISSN 2029-7025 online

2020 March Volume 9 Number 3

https://doi.org/10.9770/jssi.2020.9.3(10)

\title{
FINANCIAL SECURITY OF THE STATE
}

\author{
Oleg Reznik*, Olga Getmanets², Andrii Kovalchuk³, Vasyl Nastyuk ${ }^{4}$, Nadiia Andriichenko ${ }^{5}$ \\ 1,5 Sumy State University, 2 Rimsky-Korsakova Street, Sumy, 40000, Ukraine \\ ${ }^{2}$ Kharkiv National University of Internal Affairs, Lviv Landau avenue, 27, Kharkiv, 61000, Ukraine \\ ${ }^{3}$ State University of infrastructure and technology, st. Ivana Ogienko, 19, Kyiv, 01000 Ukraine \\ ${ }^{4}$ Yaroslav Mudryi National Law University, 77 Pushkinskaya Street, Kharkiv, 61024, Ukraine \\ E-mail: ${ }^{1 *} k o a d u e p @ g m a i l . c o m ~(C o r r e s p o n d i n g$ author)
}

Received 13 March 2019; accepted 20 December 2019; published 30 March 2020

\begin{abstract}
The article deals with the study of the financial security of the state as a component of its national security. It has been established that financial security is state's ability to react in an adequate and immediate way to internal and external negative financial influences in peacetime and in emergency situations, in particular in the context of a hybrid war. It has been established that the components of the financial security of the state are banking, debt, budget, currency and monetary security. It has been found out that corruption, financial and economic crime, hybrid war, fiscal decentralization, and lack of a strategy to protect the financial and economic interests of the state are threats to the financial security of the states in the present conditions. At the same time, proper protection of the financial security of the state against internal and external threats is possible only in case of quality management of the financial and economic sphere, first of all, this is the identification of threats to the financial security of the state, conducting of financial control, and counteraction and combating against financial and economic crimes, which is the task of law enforcement agencies. The development of the idea of creating a single law enforcement agency of Ukraine empowered to prevent, detect, suspend and investigate financial and economic crimes was considered. For comparison, attention was drawn to foreign experience, namely Italy, Romania, Macedonia, Austria, Croatia, Latvia, Lithuania, for which the activity of such law enforcement agencies is already established practice. The positive aspects which can be implemented in Ukraine as well as in other countries, intending to create a new law enforcement entity, were emphasized.
\end{abstract}

Keywords: financial system; financial security; national security; corruption; organized crime; financial police

Reference to this paper should be made as follows: Reznik, O., Olga Getmanets, O., Kovalchuk, A., Nastyuk, V., Andriichenko, N. 2020. Financial security of the state. Journal of Security and Sustainability Issues, 9(3), 843-852. https://doi.org/10.9770/jssi.2020.9.3(10)

JEL Classifications: F35, F42

\section{Introduction}

Historically, the main threat to the national security of the state was the armed conflict, which has always been provoked by the states themselves. Therefore, the concept of «security» is often understood as control of military threats. However, the situation changed in the 21 st century. Threats ceased to be limited to only military threats. The financial crisis, terrorism, proliferation of nuclear, chemical weapons, ethnic conflicts, organized crime, epidemics, overpopulation, climate change and so on began to affect the status of national security. All countries in the world are upon pain of every day, therefore there is a growing awareness that it can only be saved through the cooperation of states, international organizations, communities, etc.

The financial crisis and a number of other threats directly determined the need for states to pay attention to the protection of their financial interests, then the issue of financial security has become particularly relevant at both national and international levels. In particular, appropriate financial security strategies are being implemented, law enforcement agencies are being reformed, and new law enforcement agencies are being set up to minimize 
negative trends in the financial sector in Ukraine. For example, in 2017, the analysis of the financial security of Ukraine demonstrates that there is an excessively large share of cash outside banks in the total amount of money supply - at the level of 26-27\%, there is discrepancy between the balance of incomes and expenditures of the state and local budgets and inefficient use of public funds. Accordingly, the budgetary security of Ukraine is not even in a threatening status, but in a pre-crisis status. Not surprisingly, in accordance with international standards assessing the financial security of the state on indicators A, B, C and D, Ukraine has a rating of C (Józef Antoni Haber, et. al., 2018).

\section{Literature Survey}

Given the relevance of the issue of financial security of the state in modern conditions at the doctrinal level, a number of scientific papers is devoted to it. First of all, the scientists' opinions regarding the definition of the concept of «financial security of the state» are differed, while all scholars support the idea that the financial security of the state as an element of the economic security of the state is the core of the national security of the country on the whole (Durmanov et. al., 2019).

Thus, Britchenko, N.I. Bohomolova, O.O. Kravchenko, S.S. Pinchuk define the financial security of the economic system as achieving of such level of financial stability which will foster to the maintain of financial equilibrium and ensure targeted growth in accordance with the development strategy (Britchenko et.al., 2018).

According to Varnalii Z. and Tomashevskyi T., financial security of the state is one of the key positions of economic security when the status of public finances is directly related to the status of the national economy, while the economic well-being of the country depends largely on the level of financial security afforded to each individual, society and the nation on the whole. At the macro-level, financial security is ability of the state to react adequately to internal and external negative financial influences in peacetime and in emergencies, in particular in a hybrid war (Varnalii \& Tomashevskyi, 2019).

Kurylo M., Klochko A., Zhuravlov D., Javado, H. determine the constituent elements of the financial security of the state without considering the essence of this concept. Thus, scientists refer banking, debt, budget, currency and monetary security to the content of the financial security of the state (Kurylo et. al., 2018).

According to Galina Pochenchuk, financial security is driven by the ability of public authorities to ensure the sustainability of national financial and economic development and the payment and settlement system, compliance with the main financial and economic parameters of the national economy, optimal allocation and rational use of budget resources, as well as ability to make external borrowing optimal for the national economy and to use them effectively, to neutralize the impact of financial crises and targeted actions of international and national economic agents on the economic, social and political system of the state, to prevent the outflow of capital abroad, crimes and administrative offenses in the financial sector (Pochenchuk, 2014). Obviously, the definition proposed by the scientist is broader and allows to characterize the financial security components of the state. Thus, the status of national financial security is directly dependent on the effectiveness of its management and counteracting the internal and external threats (Sitdikova \& Starodumova, 2019).

It should be agreed with Z. Varnalii and T. Tomashevskyi that the level of threats to financial security is not a constant magnitude - it changes with the overall economic situation. The process of globalization associated with the fall in the level of state regulation and restrictions caused by the interests of certain national and economic structures plays a special role in the activation of the sphere of finances. Threats to financial security destabilize the economic situation in the country and impede the normal development of the community, also cause considerable harm to them (Varnalii \& Tomashevskyi, 2019).

Today, as Nataliia Zachosova and Nataliia Babina point out, non-traditional types of threats are becoming especially widespread. They are not traditional for financial institutions and have a significant impact on the 
results of their operation and they are called as «hybrid threats». Thus, the functioning of the financial market and its participants is currently under the control of the hybrid war caused by the conflict situation in the east of Ukraine. Accordingly, financial institutions can act as entities of hybrid warfare in the economic sphere and their products and services should be tools of war (Zachosova \& Babina, 2018; Ključnikov, Mura, Sklenár, 2019).

Corruption also plays an important role in internal threats to the financial security of the state. Therefore, we should agree with B. S. Malyniak, O. M. Martyniuk, O. P. Kyrylenko that the impact of corruption on public spending is changed depending on the level of democracy in the country. In the countries with low levels of democracy, reducing of the corruption level increases effectiveness of government spending on 0.923 units, while the similarly decreasing of corruption in the countries with the high-level of democracy will increase government spending on only 0.701 units (Malyniak, et. al., 2019).

The process of fiscal decentralization has begun, it is underway or has already completed in many countries, which fosters to transform the territorial communities and local governments into full members of the financial interconnection system. Under this reform, territorial communities receive individual financial interest. Therefore, there is also need to protect them, as these interests are the basis for creating a safe environment for the functioning of territorial communities (Bak, 2019; Korauš, et.al., 2019).

On the contrary, Siemiątkowski P. emphasizes that developing countries must pay attention to external financial dangers. Such states are more vulnerable to the effects of potential global crises and to possible activity by international speculators. In turn the states which are members of the European Union for a long time are highly developed economies that can already boast by high authority in the eyes of international investors. Even low macroeconomic indicators do not force investors to leave the market. These economies have no difficulty in acquiring external financing (even in spite of the large proportions of external debt). Although the exception is the United Kingdom, which is the second country after the United States suffered from the most economic losses after the last financial crisis. This example is rather the exception of the rule (Siemiątkowski, 2017).

Some scholars, in particular Oleksandr Sharov, considering the issue of financial security also reveals the place of the International Monetary Fund, which was created as one of the most important institutional elements of the international economic security in the mechanism of protecting the financial interests of the state. However, if there are scientists who believe that the lack of interaction of states with the International Monetary Fund impedes investment attraction in the economy of the state, Oleksandr Sharov refutes this view, noting that the lack of programs of cooperation with the International Monetary Fund is not a threat to the national economic security, since insecurity of financial and economic interests of the state at the national and international levels are likely due to the lack of real reforms and measures to improve the financial and economic situation within the country (Sharov, 2017).

However, a significant danger is financial and economic crimes for both national and international financial and economic interests of states. In the context of globalization and development of information and computer technologies, international institutions have officially recognized the 21 st century as the century of fraud. The economic crime investigations conducted annually by the international auditing firm PricewaterhouseCoopers, allowed to generalize the most common threats to economic security and their corresponding challenges in Ukraine and in the world. According to the survey, the most typical and traditional types of economic crime are: (1) misappropriation of assets; (2) bribery and corruption; (3) procurement and accounting fraud, etc. According to official data, the level of economic fraud in the world in 2016 reached the level of economic crimes in Ukraine as of 2011, and this is a common threat for all companies at the national and world markets without exception (Moskalenko, 2016). A significant threat for today is also this type of financial and economic offenses as the legalization (laundering) of criminal proceeds (Leonov, et. al., 2019). 


\section{Methods}

Both general and specific methods of scientific cognition are used for the study of the issue of financial security of the state.

In particular, the dialectical method of cognition is used to evaluate the theoretical and normative principles of understanding financial security in the structure of national and economic security. In turn, causal analysis methods are the basis for a direct analysis of the functioning of financial security in the current conditions of the Ukraine's development, while comparative methods of the analysis are used to study the similarities and differences between different elements of the state national security structure. The structural and functional method allows to reveal the specifics of the subject composition of financial security protection in Ukraine and other European Union countries.

\section{Results}

Speaking about the protection of the financial and economic interests of the state, scientists primarily focus on the subjects authorized to carry out such activities. The most important step in this direction should be to determine the list of threats affectng financial market participants and can destabilize their activities and slow down the development of the financial system of the country on the whole.

Pikhotskyi V. F., Rysin V. V., Lyubenko A. M. note that one of the tasks of the state in the direction of protecting the financial and economic security of the state is to control the use of financial and material resources. Financial control is important in the public sector, as a clear assurance of standards in the budgetary sector contributes to the social stability, economic security and a high level of social security. Society's belief in power also largely depends on the effectiveness of financial control. Ukraine has not yet implemented a single methodological basis for building an effective audit system in the public financial management sector, so the need for new theoretical and practical approaches to the development of public finance auditing is urgent. Ideally, according to scientists, the state should have a financial audit, effectiveness audit and operational audit. Accordingly, financial audit is carried out by economic entities, budgetary institutions and state and communal property entities; effectiveness audit is focused on assessing the implementation of local budgets and development programs: operational audit is aimed at checking individual business operations (Pikhotskyi, et. al., 2019).

Continuing the topic of the importance of governance in the area of financial security of the state, we should also agree with Rushchyshyn N., Buchko I., Kostak Z., who propose to optimize the management of the public debt of the state by giving the Debt Management Committee the powers in this area to promote the efficient use of external borrowing which will help to restore and develop «problem areas» of the economy and increase the state budget revenues (Rushchyshyn, et. al., 2016).

However, increase of the level of financial security of the governance itself is not enough, it is also necessary to carry out activities for the prevention, detection, termination and investigation of financial and economic crimes, which, as already mentioned, pose a significant threat to the financial security of the state. Today this task is entrusted to the relevant law enforcement agencies in all states. The process of creating a responsible law enforcement agency is still ongoing in Ukraine, as evidenced by the latest draft law "On the Bureau of Financial Investigation". Although there have been several such bills since 2013, the legislator still cannot determine the model of the future law enforcement structure (Table 1). 
Table 1. Status of the law enforcement agency responsible for counteracting and combating financial and economic crimes under the draft laws in Ukraine

\begin{tabular}{|c|l|}
\hline Name of the bill & \multicolumn{1}{c|}{ Status of the body according to the bill } \\
\hline $\begin{array}{c}\text { On the financial police } \\
\text { (2016) }\end{array}$ & $\begin{array}{l}\text { It is a state law enforcement agency, whose activities are directed and coordinated by the government } \\
\text { through the Ministers of Finance, entrusted with the duty to ensure the prevention, detection, termination, } \\
\text { investigation and detection of crimes in the sphere of formation and use of financial resources of the state, } \\
\text { economic security related to its jurisdiction, respectively, to the Criminal Procedure Code of Ukraine. }\end{array}$ \\
\hline $\begin{array}{c}\text { On the Financial } \\
\text { Investigation Service } \\
\text { of Ukraine (2017) }\end{array}$ & $\begin{array}{l}\text { It is created on the basis of tax police and a unit on combating against money laundering and it is the } \\
\text { central law enforcement agency with special status. It is composed of units for combating criminal offenses } \\
\text { in the field of economic activity, investigative units and units for combating corruption and their own } \\
\text { security. }\end{array}$ \\
\hline $\begin{array}{c}\text { On the National } \\
\text { Binancial Security }\end{array}$ & $\begin{array}{l}\text { It is a state law enforcement body, which is subordinated to the Verkhovna Rada of Ukraine, the President } \\
\text { of Ukraine, and ensures elimination of threats to the financial security of the state on the basis of criminal } \\
\text { analysis, risk analysis. It is carried out by preventing, detecting, suspending, investigating and solving } \\
\text { crimes related to its subsidiarity, which directly or indirectly damage public finances and prevent them } \\
\text { from being committed in the future. }\end{array}$ \\
\hline $\begin{array}{c}\text { On the Bureau of } \\
\text { Financial Investigation } \\
\text { (2019) }\end{array}$ & $\begin{array}{l}\text { It is a central executive body implementing the state policy on the prevention, detection, termination, } \\
\text { investigation and disclosure of criminal offenses in the field of economic activity that directly or indirectly } \\
\text { harm the public interest in the field of finance }\end{array}$ \\
\hline \multicolumn{2}{|l}{}
\end{tabular}

In general, the idea of creating a law enforcement agency countering and combating financial and economic crimes in the country is supported by scientists, experts and the public. But the question remains of defining a unified concept for the creation and operation of such body, since a number of bills is testified the opposite. In order to better understand the direction of Ukraine in the area of protection of the financial and economic interests of the country, it is necessary to pay attention also to foreign experience, its expediency to study is also confirmed by the provisions of the Recommendations of the Working Group "Prospects for Cooperation of Ukraine and the European Union in the Area of Justice, Freedom and Security", 2012 , which require a review of the powers and number of law enforcement agencies that counteract crime in the Ukrainian economy (staff reduction, eliminating certain structures).

In general, the experience of foreign countries demonstrates that the functioning of a single law enforcement agency entrusted combating with financial and economic crime is not new and such entities have been operating effectively in most states for a long time (Table 2).

Table 2. Subjects empowered to combat and counter the financial and economic crimes in European countries

\begin{tabular}{|c|c|}
\hline State & Authorized entity \\
\hline Italy & Financial Guard (Ministry of Economy and Finance) \\
\hline Romania & Financial Guard (Ministry of Economy and Finance) \\
\hline Macedonia & Financial Crime Investigation Bureau (Ministry of Finance) \\
\hline Austria & Financial Police (Ministry of Internal Affairs) \\
\hline Croatia & Financial Police (Ministry of Finance) \\
\hline Latvia & State Revenue Service (Ministry of Finance) \\
\hline Lithuania & Financial Crimes Investigation Service (Ministry of Internal Affairs) \\
\hline
\end{tabular}

Thus, among the countries of the European Union, one of the most effective law enforcement agencies in protecting the financial and economic interests of the state operates in Italy. The organizational and functional model of the Financial Guard of Italy indicates that it occupies an important place in the system of executive authorities and the Italian law enforcement system. To date, the tasks of the Financial Guard of Italy, which is directly subordinated to the Ministry of Economy and Finance and it is an integral part of the armed forces of the state, include:

(a) tax control; 
(b) supervision of excise duties;

(c) customs control, control of public expenditure;

(d) counteracting organized crime;

(e) combating against counterfeiting;

(f) fraud prevention and counteraction within the European Union system;

(g) oversight of lawfulness in public procurement, tendering;

(h) organizing interaction with other law enforcement and regulatory authorities in the country (Adeguamento dei compiti del Corpo della Guardia di finanza, 2001).

In Romania, control over compliance with tax laws, prevention, detection and investigation of tax evasion and tax fraud is entrusted on the Finance Guard of Romania, which is subordinated to the Ministry of Economy and Finance. Accordingly, the Financial Guard of Romania conducts the financial control and checks on compliance with regulations to prevent, detect and terminate actions prohibited by law, trade rules to prevent, detect and eliminate illegal trading operations, order of manufacture, storage, movement and sale on the territory of the state. The objectives of financial control carried out by the Financial Guard are:

(1) compliance with financial and economic discipline and budgetary requirements in terms of income and expenditure;

(2) compliance with the lawfulness of the management of financial and material funds in national joint-stock companies where the state is a shareholder, directly or indirectly through an institution or body of state power;

(3) compliance with the targeted use of the state aid;

(4) compliance with the obligation to pay taxes and fees to the State (Financial Police Office).

The Financial Crime Investigation Bureau in Macedonia is the subject of protection of the financial and economic interests of the state against unlawful encroachments, it is also subordinated to the Ministry of Finance. Today Macedonia's Financial Crime Investigation Bureau:

(a) provides financial control, control over the application of tax, customs and other financial rules;

(b) identifies and documents criminal cases, foremost in the area of combating with organized crime;

(c) carries out preliminary investigative steps;

(d) initiates and conducts misdemeanor proceedings in misconduct cases, and initiate misdemeanor proceedings in misconduct cases if the fact of a of financial law violation in the exercise of their powers is discovered.

(e) prepares and provides expert opinions and recommendations within its competence at the request of other public authorities and institutions (Regulamentul de organizare şi funcţionare a Gărzii Financiare, 2010). It should be noted that the bodies counteracting the financial and economic crime of Romania and Macedonia have fewer powers than the Italian Financial Guard.

Similar bodies also operate in Austria, Croatia, Lithuania, Latvia, etc. Yes, the Austrian Financial Police is a special unit of the Austrian police to combat tax fraud related to tax evasion and social security deductions. In 
order to identify tax evasion, social deductions, shadow economy, the Austrian Financial Police is entitled to carry out targeted audits (Finanzpolizei). The Financial police also operate in Croatia, but structurally it is a part of the Ministry of Finance system and it is headed by its director, who is appointed to the post by the country's government on the proposal of the Minister of Finance. According to the Law of Chortia "On Financial Police of Croatia" No. 177/04, this body is responsible for control over:

(1) the use of budgetary funds;

(2) following the order of reflection and accounting in the accounting documents of the goods and services sale, income, profit;

(3) registration of taxable movable and immovable property in the tax authorities;

(4) accuracy of the declared data giving the right to reduce or exempt tax liabilities (Zakon o financijskoj policiji).

The State Revenue Service has been operating in the Republic of Latvia since 1993, it is a public administration institution subordinated to the Minister of Finance. An important place in the structure of this service belongs to the Financial Police Department, whose main tasks are:

(a) conducting operational activities to detect and prevent crimes in the field of public revenue;

(b) investigation of offenses in the field of public revenue (Law of the Republic of Latvia on the State Revenue Service, 1995).

The body specialized in the combating against financial crimes is under the jurisdiction of the Ministry of Internal Affairs in Lithuania. In particular, the Financial Crimes Investigation Service is a special law enforcement agency whose purpose is to identify and investigate crimes and other related offenses that harm the financial system of the state. The Financial Crimes Investigation Service executes the following tasks:

(1) identifying and investigating fraudulent or negligent taxpayer accounts, misrepresentation of tax information, state (municipal) fees, tax evasion, contributions to state social security, and other payments, report failure approved in due course;

(2) detecting and investigating actions related to the legalization of money or property obtained from criminal activity, illicit circulation of securities, and other fraudulent activities related to the financial system except the facts of counterfeiting;

(3) identification and investigation of crimes and other offenses related to the receipt and use of financial assistance from the European Union and foreign countries;

(4) cooperation with law enforcement agencies and other institutions of Lithuania and foreign countries, international organizations on the issues within the competence of the indicated service;

(5) taking measures to prevent tax evasion, state (municipal) fees and other payments, misappropriation and funds waste of state and municipal property, financial assistance from the European Union and foreign countries;

(6) collection and analysis, summarization and information on the illicit receipt and use of financial assistance from the European Union and foreign countries;

(7) preparing proposals for the improvement of regulations governing the investigation of crimes and other offenses against the financial system (Law of the Republic of Lithuania on the Financial Crime Investigation Service). 


\section{Discussion}

Considering the importance of protecting the financial and economic interests of the state, the establishment and operation of a law enforcement agency responsible for preventing, detecting, suspending and investigating financial and economic crimes is one of those pressing issues. On the plus side, Ukraine respects the recommendations of international institutions and the best practices of foreign countries and is moving towards the creation of a specified law enforcement structure. On the negative side, various draft laws have been registered in the Verkhovna Rada of Ukraine since 2013, which suggested defining the legal basis for the creation and operation of a law enforcement agency in the area of counteracting and combating financial and economic crime. However, none of them was accepted.

Without going into details of the draft laws, it should be noted that there are two issues to be debated. The essence of the first question is that most scientists see only the formality of establishing a single law enforcement agency to prevent, detect, suspend and investigate financial and economic crimes at the tax police units of the State Fiscal Service of Ukraine. And the second question is related to the warning of scientists that the new law enforcement structure will receive powers to counteract and combat financial and economic crime from existing law enforcement agencies as subjects of financial and economic security of Ukraine, whose implementation will be difficult to control, which can lead to abuse their powers by the authority.

However, such processes can be avoided by providing the implementation of integrated control over a single law enforcement agency in the field of counteracting and combating with financial and economic crimes in the country in the current legislation.

\section{Conclusions}

Thus, the financial security of the state is a core not only of the economic but also the national security of the state, considering that the issue of its security should be paid significant attention at the national and international levels, which is relevant in the context of globalization and a number of other factors negatively affecting the financial and economic situation in the state and the world.

Scientists understand the financial security of the state as protection of the financial and economic interests of the state against internal and external unlawful threats. Corruption, financial and economic crime, fiscal decentralization, hybrid war, lack of a strategy to protect the financial and economic interests of the state belongs to the threats of the financial security of the state. Of course, this list is not exhaustive, because, new challenges are emerging every day for countries in the financial and economic sphere in the context of globalization and the constant development of computer technologies.

An important role belongs to the quality management of the financial and economic sphere in the direction of improving the status of the protection of the state's financial and economic security, but nonetheless an important role belongs to activities in the field of countering and combating financial and economic crimes, including misappropriation of assets, corruption, fraud in public procurement, tax evasion, other statutory fees. Such a task is entrusted to law enforcement agencies, it is usually one law enforcement agency in each state. In view of this, Ukraine also seeks to delegate all powers of preventing, detecting, terminating, investigating of financial and economic crimes to a single entity, but the sole concept of creating and operating the indicated body has not yet been reflected in the relevant law.

Experience of foreign countries demonstrates that Ukraine is on the right track, since there are similar entities in the countries of the European Union: Italy - Financial Guard, Romania - Financial Guard, Macedonia Financial Crime Investigation Bureau, Austria - Financial Police, Croatia - Financial Police, Latvia - State Revenue Service, Lithuania - Financial Crimes Investigation Service. These are not all examples of states that confirm the feasibility of establishing a law enforcement agency in Ukraine in the field of contaracting and combating financial and economic crimes. This is evidenced by a number of other benefits: 
the existence of one entity responsible for the prevention, detection, termination and investigation of financial and economic crimes; (2) possibility of establishing better cooperation of the new law enforcement agency with the relevant structures of foreign countries; (3) simplification of the mechanism of control over activity of the specified law enforcement structure.

\section{References}

Adeguamento dei compiti del Corpo della Guardia di finanza, a norma dell'articolo 4 della legge 31 marzo 2000, n. 78: Decreto Legislativo 19 marzo 2001, n. 68. Gazzetta Ufficiale. 2001. № 71.

Britchenko I., Bohomolova N. I., Kravchenko O. O., Pinchuk S. S. (2018). Assessment of The Determinats of Financial Security of Railways in Ukraine. Financial and credit activity: problems of theory and practice. DOI: https://doi.org/10.18371/fcaptp.v 4i27.154109

Durmanov, A., Bartosova, V., Drobyazko, S., Melnyk, O., Fillipov, V. (2019). Mechanism to ensure sustainable development of enterprises in the information space. Entrepreneurship and Sustainability Issues, 7(2), 1377-1386. http://doi.org/10.9770/jesi.2019.7.2(40)

Financial Police Office. URL: https://finance.gov.mk/en/node/813

Finanzpolizei. URL: https://www.bmf.gv.at/betrugsbekaempfung/finanzpolizei/finanzpolizei.html\#Aufgaben_der_Finanzpolizei

Haber, J,A., Bukhtiarova, A., Chorna, S., Iastremska, O., Bolgar, T. (2018). Forecasting the level of financial security of the country (on the example of Ukraine). Investment Management and Financial Innovations, 15(3), 304-317 http://doi.org/10.21511/imfi.15(3).2018.25

Ključnikov, A., Mura, L., Sklenár, D. (2019). Information security management in SMEs: factors of success, Entrepreneurship and Sustainability Issues, 6(4), 2081-2094. http://doi.org/10.9770/jesi.2019.6.4(37)

Korauš, A., Gombár, M., Kelemen, P., Backa, S. (2019). Using quantitative methods to identify insecurity due to unusual business operations, Entrepreneurship and Sustainability Issues, 6(3), 1101-1012. http://doi.org/10.9770/jesi.2019.6.3(3)

Kurylo, M., Klochko, A., Zhuravlov, D., Javadov, H. (2018). Economic and legal aspects of banking security under European integration intensification in Ukraine. Banks and Bank Systems. http://dx.doi.org/10.21511/bbs.13(1).2018.15

Law of Republic of Lithuania "On the Financial Crime Investigation Service" (2002). URL: http://www.fntt.lt/data/public/-uploads/2016/10/lawonthefinancialcrimeinvestigationservice1.pdf

Law of the Republic of Latvia “On the State Revenue Service” (1995). URL: http://www.pb2010.1v/content/materials/pb2015/files/z_ sgd-2015ru.pdf

Leonov, S., Yarovenko, H., Boiko, A., Dotsenko, T. (2019). Information system for monitoring banking transactions related to money laundering. CEUR Workshop Proceedings, 2422, pp. 297-307.

Malyniak, B. S. Martyniuk, O. M. Kyrylenko, O. P. (2019). The Impact Of Corruption On The Efficiency Of Public Spending Across Countries With Different Levels Of Democracy. Financial and credit activity: problems of theory and practice. 28(1), 290-301. https://doi.org/10.18371/fcaptp.v1i28.163927

Mohamed Muhumed (2016). The Effect of F inancial C risis on International Security. URL: https://www.researchgate.net/ publication/311867747_The_Effect_of_Financial_Crisis_on_International_Security

Moskalenko, M. (2016). Critical Issues of Economic Security of Organizations. Economics of Development, 1(77), 69-76.

Nataliia Bak (2019). Financial Security of Territorial Communities In Ukraine: Content/ Components, Threats. World of Finance, 1(58), $98-110$

Pikhotskyi, V. F., Rysin, V. V., Lyubenko, A. M. (2019). Effectiveness of Financial Control and State Audit In Providing The Financial And Economic Stability Of The State. Financial and credit activity: problems of theory and practice. DOI: https://doi.org/10.18371/ fcaptp.v1i28.164008

Pochenchuk, G. (2014). Issue of Country Financial Security Governance. Forum Scientiae Oeconomia, 2(2), 29-37.

Regulamentul de organizare şi funcţionare a Gărzii Financiare (2010). URL: http://lege5.ro/Gratuit/geztemjzhe/regulamentul-de-organizare-sifunctionare-a-garzii-financiare-din-12022010

Rushchyshyn, N., Buchko, I., Kostak, Z. (2016). Public debt of Ukraine: current status and options for its optimization. Economic Annals-XXI, 161 (9-10), 75-78. 
Sharov, O. (2017). Ukraine-IMF Relations as an Important Factor Of The National Economic Security. Journal of European Economy, 16. 3(62), 315-340.

Siemiątkowski, P. (2017). External financial security of the European Union member states outside the Eurozone. Journal of International Studies. http://doi.org/10.14254/2071-8330.2017/10-4/6

Sitdikova, L.B.; Starodumova, S.J. (2019). Corporate agreement as a means of providing security in the course of entrepreneurship development, Entrepreneurship and Sustainability Issues, 7(1), 324-335. http://doi.org/10.9770/jesi.2019.7.1(24)

Z. Varnalii, T. Tomashevskyi (2019). Financial Security Of Ukraine in Hybrid War. Bulletin of Taras Shevchenko National University of Kyiv. Economics. https://doi.org/10.17721/1728-2667.2019/204-3/1

Zachosova N., Babina N. (2018). Identification of Threats to Financial Institutions' Economic Security as an Element of the State Financial Security Regulation. Baltic Journal of Economic Studies https://doi.org/10.30525/2256-0742/2018-4-3-80-87

Zakon o financijskoj policiji. URL: http://www.zakon.hr/z/197/Zakon-ofinancijskoj-policiji

Short biographical note about the contributors at the end of the article:

Oleg REZNIK, Doctor of Science of Law, Assotiate Professor, Sumy State University

ORCID ID: orcid.org/0000-0003-4569-8863

Olga GETMANETS, Doctor of Science of Law, Professor, Kharkiv National University of Internal Affairs

ORCID ID: orcid.org/0000-0003-2587-4412

Andrii KOVALCHUK, Doctor of Science of Law, Department of Justice State University of infrastructure and technology ORCID ID: orcid.org/0000-0001-5471-6432

Vasyl NASTYUK, Doctor of Science of Law, Professor, Corresponding Member of the National Academy of Legal Sciences of Ukraine, Honored Worker of Science and Technology of Ukraine, Yaroslav Mudryi National Law University

ORCID ID: orcid.org/0000-0002-4312-7826

Nadiia ANDRIICHENKO, postgraduate, Sumy State University

ORCID ID: orcid.org/0000-0002-0282-2775

This work is licensed under the Creative Commons Attribution International License (CC BY)

http://creativecommons.org/licenses/by/4.0/ 